\title{
進化する図書館蔵書検索サイト「カーリル」
}

\section{CALIL.JP, a new web service that provides one-stop searching of Japan-wide libraries' collections}

吉本 龍司 ${ }^{1}$

\section{YOSHIMOTO Ryuuji ${ }^{1}$}

1 Nota,Inc.（厂602-8233 京都府京都市上京区福大明神町128） E-mail : ryuuji@notaland.com

1 Nota,Inc. (128 Fukudaimyojin-Cho Kamikyo-Ku Kyoto-Shi, Kyoto 602-8233)

原稿受理 (2012-03-07)

情報管理５5(2), 97-105, doi: 10.1241/johokanri.55.97 (http://dx.doi.org/10.1241/johokanri.55.97)

\section{著者抄録}

図書館蔵書検索サイト「カーリル」は，無料で利用できるWebサービスである。全国の図書館が，Web-OPACにより 提供する書籍の所蔵情報を，横断的に抽出し，整理・統合した上で，利便性の高いユーザーインターフェースにより 利用者に提供している。カーリルは，楽しい本との出会いを提供し，図書館に足を運ぶきっかけをつくることをコン セプトに開発が進められた。サービス開始時は，主に公共図書館の利用者を対象としたサービスであったが，現在では， 大学図書館や専門図書館への対応も進んでいる。本稿では，サービス立ち上げから開発に携わり，現在，エンジ二ア としてカーリルの開発マネージャーを担当する筆者の立場から，カーリルの基本的な機能やコンセプト，サービス提 供開始以降の進化と，今後の展開について紹介する。

キーワード

図書館，OPAC，蔵書検索，Webサービス，横断検索，地域資料，API，カーリル，カーリルローカル，カーリルアカ デミア

\section{1.はじめに}

図書館蔵書検索サイト「カーリル」は, Nota, Inc. が提供する無料のWebサービスである。カーリルは， 全国の図書館がWeb-OPACにより提供する書籍の所 蔵情報を，リアルタイムに統合することに成功した。 2010年3月にWeb利用者をターゲットとしてサービ スを開始したが，現在では相互貸借のための情報収 集など，図書館業務の中でも多く利用されている。

カーリルは現時点で唯一，日本国内の5,900以上の 公共，大学，専門図書館・図書室に対応した所蔵情
報の横断的検索システムである（図1）。

利用者は，最初に地域を選ぶと，近くの図書館や 相互貸借できる図書館など複数の図書館からわかり やすいデザインで蔵書を探すことができる。また蔵 書がなければオンライン書店において購入が可能で ある。そのほか，既存の書籍や図書館に関するWeb サービスと積極的に連携し，利用者にとつて総合的 に書籍を楽しむことができるような工夫を盛り込ん でいる。本稿では，サービス立ち上げから開発に携 わり，現在，エンジニアとしてカーリルの開発マネー ジャーを担当する筆者の立場から，カーリルの基本 


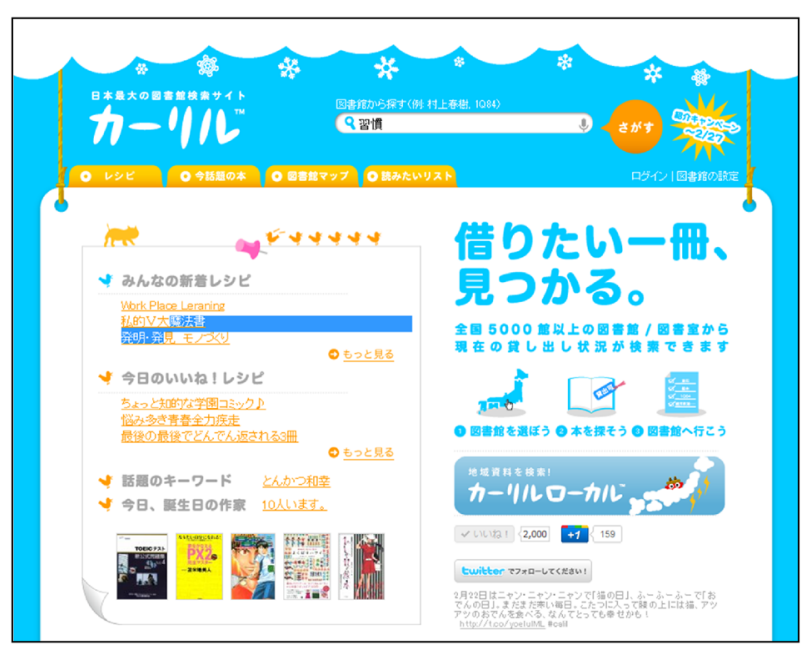

図1 カーリルのトップページ

的な機能やコンセプト，サービス開始以降の進化と， 今後の展開について紹介する。

\section{2. 開発の背景}

筆者は，ある地方自治体のシステムコンサルティ ングの一貫として公共図書館のシステム検討に関 わった経験がある。その自治体ですでに導入されて いた蔵書検索や予約などのWebサービスは，多額の 費用をかけているにも関わらず，ほとんど利用され ていなかった。

システムの使い勝手が悪いというだけではなく， サービスを提供する図書館職員のWebサービスに対 する知識が少なく，積極的に利用者にアピールされ ていないなど，運用上の課題も多かった。

このような経験を交えながら，開発メンバーとブ レインストーミングによって話し合う中で「楽しい 図書館蔵書検索」というアイデアが生まれた。図書 館の蔵書検索は，本来，本を発見し出会う楽しみが あるはずであり，そのような蔵書検索システムが実 現できれば，利用者は積極的に蔵書検索を利用し， 結果として図書館に足を運ぶ機会も増えるのではな いか。このような仮説をもとにシステムの設計を開 始した。

\section{3. 目標の設定}

カーリルは，「楽しい蔵書検索」と「図書館利用の きっかけとなること」を目標とした。目標を実現す るため，具体的に，以下に述べる要件を設定した。

\section{1 楽しいデザイン}

最初に図書館を訪れるのは，子どもの頃であるこ とが多いと思うが，われわれはこの図書館の原体験 を重視した。すなわち，カラフルな本が本棚にずら りと並んでおり，1つずつ手にとるときの喜びをサイ ト上でなるべく再現することを目指した。そのため には，書影が並んでおり，ボタンを押すことで次々 と検索結果を眺めることができる必要がある。

また，図書館に行った経験が少ないユーザーにも 先入観なくサービスを利用してもらえるよう，あえ て「図書館らしさ」を感じさせない，明るく，楽し いデザインとする。

システムの制約上，検索に時間がかかる場合もあ るが，その場合はアニメーションを活用することで ユーザーを飽きさせない工夫を行う。

\section{2 全国の図書館に対応}

日本国内でWeb-OPACを導入した公共図書館は 80\%を超えている（カーリル調べ）。カーリルはこれ らすべてに対応することで，日本全国の公共図書館 を網羅することを目指している。

普段使っている図書館や近くの図書館がカーリル に対応していないという状況が多ければ結果として 利用は広がらない。全国規模のWebサービスとして は，ほぼすべての図書館に対応していると言えるだ けの規模の対応が必要である。

公共図書館だけでも，居住地，通勤場所，通学場 所や都道府県立図書館など，いくつかの図書館を組 み合わせて使う場合も多い。そのため，利用できる 図書館を選択し，まとめて検索できる必要がある。 


\section{3 図書館にない書籍も検索}

従来のWeb-OPACは，自館に所蔵のある書籍しか 検索できないことが多い。図書館にない書籍を検索 するとき，利用者は，結果がゼ口件と表示されても， 他のキーワードの可能性などを考え，何度もキーワー ドを入力しなおす可能性がある。これは無駄な行為 であり，検索システムへの信頼も落とすことになる。

また，われわれが司書に行ったヒアリングによれ ば，多くの司書が利用者から自館にない書籍に関す る問い合わせを受けたときに，Amazonなどのオンラ イン書店を検索システムとして利用していた。

これらの問題は，図書館にない書籍も同時に検索 結果に表示できるようにすれば解消できる。司書は 手間を軽減でき，利用者は発見した書籍を図書館に リクエストしたり，書店で購入することができる。

\section{4 図書館に行くきっかけ}

カーリルでは，人々が図書館に行くきっかけをつ くることを目指している。そのため，初めて図書館 に行くユーザーでも図書館を探すことができるよう， 地図や口コミなど図書館についてのさまざまな情報 をあわせて提供する必要がある。図書館の口コミを 投稿できる「全国図書館スタンプラリー」機能など， Web上のサービスとして完結するのではなく，利用 者が図書館とWebを循環することを目指している。

\section{5 外部サービスとの連携}

インターネット上のサービスは日進月歩で発展し ており，利用者が本のレビュー（書評）を投稿でき るサイトや，本棚を作成して共有できるサイトなど が多く存在する。利用者は，これらのサイトを通し て書籍を発見し，書籍を通じて友人とのコミュニケー ションを楽しむ。

図書館の検索システムは，これらのサービスと連 携し，書籍に対する総合的な利便性を利用者に提供 することが求められている。

\section{4. 開発手法}

カーリルの開発と，従来のベンダーによるシステ 厶開発とは，その手法において異なる点がある。カー リルは，構想から公開までかかった期間が2か月と短 かったことが特徵である。本章では，カーリルの開 発手法について述べる。

\section{1 開発チームの構成}

カーリルの開発チームが住んでいる地域は京都， 中津川，東京などに分散しており，それぞれにオフィ ス（または作業場）がある。普段はSkypeなどを使っ てコミュニケーションをとっている。担当業務は 「ディレクション」「API開発」「インターフェース開発」 「デザイン制作」「図書館データベース管理」「ユーザー サポート」などとなっている。現在，カーリルに関わっ ているメンバーは6名である。少人数で各地に分散し ながら開発しているのが特徵である。

\section{2 ラピッドプロトタイピング}

カーリルは，ラピッドプロトタイピングの手法を 用いて開発を進めた。アイデアをまず動く状態にし てから，その成果を反映しながらシステムを設計す る。特に使い捨て型プロトタイピングと言われる手 法である。

約2日間の合宿による，プロトタイプの開発作業に より，一部の都道府県の公共図書館を網羅する所蔵 データの取得と，検索画面などのプロトタイプが完 成した。これらの成果をもとに，本格的な設計・開 発を開始した。

\section{5. カーリルのシステム}

本章では，カーリルのシステムや実現のために用 いた技術の詳細について述べる。 


\section{1 基本設計}

カーリルはすべてプログラミング言語のPythonに よって実装されている。OSに依存しない標準ライブ ラリのみを利用することにより，サーバー環境に依 存することなく，さまざまな環境に簡単に展開でき るよう設計されている。

\section{2 スクレイピング}

Web-OPACを構成するHTMLから，所蔵情報などの メタデータを解析して取り出す「スクレイピング」を いかに効率的に開発するかが，重要な課題であった。

多くの都道府県図書館などが提供する横断検索シ ステムも，基本的には，このスクレイピングにより 実現されている。しかしながら，各図書館のWebOPACごとにプログラムの開発が必要であり，システ ム更新やカスタマイズ等にも追随してプログラムを 修正する必要がある。そのため，仕様が变わり一度 検索対象から外れてしまったWeb-OPACは長期間利 用できなくなることも多い。

カーリルでは，Web-OPACに最適化したスクレ イピングライブラリを開発し，すべての図書館を Pythonクラスとして定義することにより，より少な いコードで柔軟に開発できるスクレイピングフレー ムワークを開発した。

各ベンダーの図書館パッケージシステムを，バー ジョンごとに中間クラスとして定義し，共通の処理 はそれを継承することで，各図書館システムのプロ グラム記述はカスタマイズ部分のみに整理されるよ うになっている。また，図書館パッケージシステム ごとに一般に行われるカスタマイズを自動的に検出 し，追随するようにすることで，システム更新に伴 うカーリル側の対応コストを抑えている。

\section{3 負荷制御}

Web-OPACの中には同時アクセスに対して著しく 性能が悪かったり，連続したアクセスに対してアク セス不能に陥るなどの不具合を抱えていたりするも
のも多い。このため，システムごとに負荷を適切に 制御することによりトラブルを防いでいる。

これらの負荷制御は分散メモリ技術「memcache」 を利用して，分散された複数のサーバーで処理して いる状況であっても情報を常に共有して特定のWebOPACに対して過負荷とならないように制御するもの である。

サービス開始当初は，一部のパッケージシステム が，カーリルがアクセスしたことによる負荷により 停止するなどのトラブルがあった。これらの問題は カーリル側の負荷制御とベンダー側の不具合修正に より解決している。

同時に，カーリルでの利用者数が多く，また常識 的なWebシステムの応答速度と比べて，著しく性能 の低いシステムについては該当の図書館や開発元に 性能の向上を要請するなど，ユーザーの満足度向上 の取り組みを実施している。これらの性能の低いシ ステムは，データベースへのインデックス設定の不 足など，導入時の作業漏れなどによるものも多いと 考えられる。

\section{4 管理技術}

カーリルが現在対応しているWeb-OPACのシステ ムは，2,000を超えている。一般的に図書館システム は5年程度で更新される上，随時のカスタマイズや新 館オープンなどに伴い仕様が変更となる。それに追 随するためのスクレイピングプログラムの変更は毎 日発生している（図2）。

これらの管理コストを最小化することは，民間企 業であるわれわれにとつては最大の課題である。前 述の通り，パターン化されたカスタマイズを自動検 出する機能に加え，スクレイピング時に発生した HTTPエラ一や解析エラ一を統計的に処理することに より，システムの変更を早期に検出することができ るようになっている。

このような管理システムの整備により，WebOPACの仕様が変更された場合も，短期間で対応でき 


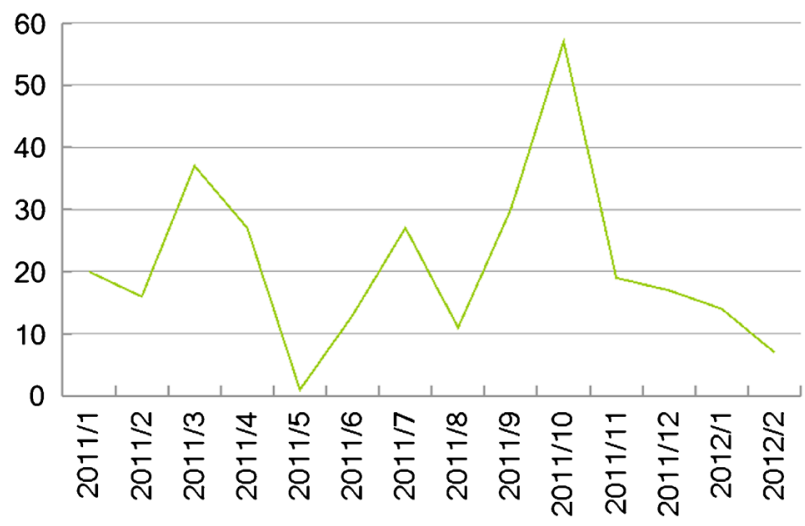

図2 月別の大規模なシステム更新件数の推移

るようになった。

\section{5 クラウドの活用}

前述の通り，OSに依存しないスクレイピングエン ジンの活用により，カーリルで最もサーバー資源を 消費するスクレイピング処理は，GoogleやAmazon が提供するクラウドサーバーや，国内のデータセン ターに設置した自社サーバーなどさまざまな環境で 分散して動作可能となった。このため、コストパ フォーマンスと処理スピードのバランスをとりなが ら，常にその割り当ての調整を行っている。負荷対 策だけではなく，障害時のバックアップとしてもク ラウドを活用することで安定したサービスの提供が 可能となった。

\section{6 図書館APIの提供}

カーリルは，横断検索機能を外部の開発者も利用 できるように「図書館API」として公開している。 APIとはApplication Programming Interfaceの略で， 共通の規格で他のシステムと連携するための仕組み のことである。これによって，外部開発者は，新た に図書館の横断検索システムを開発しなくてもカー リルの検索機能を利用した新しいサービスやアプリ ケーションが開発できる。

現在，次に挙げる2つのAPIを提供している。

(1) カーリルに対応した図書館情報の取得。

(2)ISBNと図書館を指定することにより蔵書の有無

と貸出状態（「貸出中」「貸出可」「館内のみ」な

ど）を取得。

なお，詳しい開発の方法は，Webサイトの図書館 API仕様書を参照してほしい。活用例については次の 章で述べることとする。

\section{6. 図書館とWebをつなぐカーリル}

Webサービスにおいて外部との連携はユーザー の利便性だけではなく利用の広がりを考えたときに 必要不可欠な要素である。これまで図書館がWebOPACにより提供してきたWebサービスはこの点が欠 如していた。開発時に目標として定めた「図書館利 用のきっかけとなること」を念頭に，カーリルは全 国の図書館に代わってこれを解決し，図書館とWeb の世界を境目なくつなぐことを目指している。

\section{1 検索エンジン}

検索エンジンに登録され，検索結果に表示される ようにすることは外部からのアクセス機会をつくる ために重要な要素である。検索エンジンに登録され るためには，最低限，書誌ごとにURLが永続的に維 持されるパーマリンクが必要となるが，既存のほと んどのWeb-OPACにおいては未だパーマリンクが実 現されていない。カーリルではパーマリンクを提供 することにより検索エンジンから図書館につながる 入りロとなる。

\subsection{Webサービス}

多くのWebサービスと相互連携を進めることで， 新しい利用者が増えている。「ブクログ」，「メディア マーカー」など個人の読書記録の管理サービスや、「国 立国会図書館サーチ」，「CiNii Books」などの書籍検 索サービスと広く連携することで，カーリルの提供 する機能をさまざまな場面で利用できるようになっ ている。 


\subsection{SNS}

「Twitter」や「Facebook」などに代表されるSNS (ソー シャルネットワーキングサービス）からの利用も多 い。

これらのサービスで，知り合いに本を紹介する際 には，書籍を「買う」という行為に対するリンクと して，Amazonへのリンクが広く一般的に利用されて いる。カーリルを用いることで，書籍を「図書館で 借りる」という行為に対して共通のリンクを設定で きるようになった。カーリルへのリンクが設定され ていれば，数回のクリックで友人が感想を書いた書 籍を近くの図書館に予約することが可能となった。

\section{4 地図情報}

Yahoo! JAPANの運営する地域情報サイト「Yahoo! ロコ」をはじめ多数の地図情報サービスに図書館の 施設情報を提供することで，地図情報として図書館 を検索しやすくする取り組みを進めている。また， 図書館に関するロコミなどの情報を充実して，検索 エンジンや地図情報サービスにメタデータとして提 供することで図書館に行くきっかけになると考えら れる。

\subsection{Web-OPAC}

OpenURLによる標準的なシステム連携に対応し ているため，Web-OPAC側からカーリルに連携する ことが容易となっている。カーリルとの連携機能が Web-OPACの標隼機能として提供されることも多く なっている。

カーリルと連携することにより，他館の所蔵に簡 単にアクセスできるだけではなく，インターネット 上のさまざまなWebサービスにも連携することがで きるようになる。

さらに，企業図書館など所蔵情報をWebに公開 していない場合でも，限定された利用者のみがカー リル上で所蔵情報を検索できるようにする取り組み 「カーリルスポット」の開発も進めている。

\section{6 図書館APIの利用}

カーリルが図書館APIにより提供するデータを活用 し，さまざまなWebサービスやアプリケーションが 開発されている。

図書館に関するWebサービスやアプリケーション が増えることで図書館への注目が高まり，それらの サービスがカーリルともシームレスに連携する。結 果としてカーリルの利用も増加している。

「Libron」1) はAmazonのサイト上で，図書館の蔵書 の有無を調べることができるブラウザ拡張である。

「Libreq」2）は，Twitterを通して，図書館への蔵書 のリクエストが行われたつぶやきを集計するシステ ムである。現時点では公式に図書館とは連携してい ないので，図書館へのリクエストを独自に集計して いるサイトであるが，登録された書籍が図書館に所 蔵されるとWebサイト上に表示され，利用者に通知 する機能がある。

この他，スマートフォン（多機能携帯電話）の iPhoneやAndroid上で，GPS情報を利用して利用者の 現在地点を取得し，近隣の図書館を地図上に表示し たり，自動的に最寄りの図書館から蔵書を検索した りできるシステムもある。

これらはいずれもカーリルの図書館APIをシステム の一部に利用している。図書館APIは現在のところ， 法人よりも個人のほうが開発者が多い。図書館の利 用者の中で開発技術のある市民が，カーリルAPIを利 用して便利なものを自主的に開発している。このよ うな自主的な活動によって開発，公開されたシステ ムが，他の市民にも便利に利用されている。

また一部の開発者は，アプリケーションを少額で 販売したり，サイトからアフィリエイト収入や広告 収入を得たりしている。

|丁を利用したサービスは，広範囲にわたり，1つの 開発事業者のみですべての利用者のニーズを満たす ことは難しくなっている。新しい携帯端末への対応 や，図書館以外の地域行政サービスとの連携，高齢 者や子供，障害者，外国人向けの特殊なシステムの 
開発などさまざまな用途へ柔軟に対応するためにも， 図書館APIは有効に活用できる。

\section{7. 進化するカーリル}

カーリルはサービス提供以来，Twitterなどのソー シャルメディアを通して常にユーザーとの対話を行 いながらニーズを把握し，またチーム内での議論を 重ねながら進化を続けている。この章では，カーリ ルのサービス提供開始後に追加された機能を中心に 紹介する。

\section{1 カーリルアカデミア}

前述の通り，当初，カーリルは主に公共図書館を 対象として開発された。しかし，「検索対象として大 学の図書館を設定したい」との要望が多く寄せられ た。要望は主に大学の学生や教員などからであり， 公共図書館と大学図書館を同時に検索したいという 意見も多かった。

当初，大学図書館はNACSIS-CATなどの相互貸借に 対応したシステムが整備されているため，カーリル での対応は不要と考えていた。しかし，教員からカ一 リルに対応するよう要望されたなどの理由により， 大学図書館からも直接問い合わせがあるなど，二ー ズは高まっていった。

このため，2010年9月から大学図書館への対応プロ ジェクトを「カーリルアカデミア」と名づけ，大学 図書館への対応を開始した。

現在では1,076館の大学図書館（分館を含む）に対 応している。

\section{2 カーリルローカル}

カーリルでは，ISBNをキーとして書誌と所蔵を紐 付けている。そのため，特に公共図書館が扱う資料 の中では地域資料にはISBNがついていないものが多 いため，検索ができないという問題を抱えていた。

一方で都道府県図書館により提供される横断検索
サービスは多額の費用をかけているにも関わらず， 予算不足などの理由からプログラムの变更が間に合 わないなどの問題が発生していた。

これらの問題を解決するため，キーワードをキー とした書誌検索をカーリルのスクレイピングや負荷 制御の技術を用いて実現したのが「カーリルローカ ル」である。2011年2月から公開している。

カーリルローカルでは，ユーザーが自由な図書館 の組み合わせを指定して横断検索サイトを立ち上げ ることができる。基本的な機能としては，一般的な 横断検索システムと変わりはないが，シンプルなデ ザインと高速な処理速度が特徵である。

このサービスは特に図書館の業務の中で利用され るケースが増えている。

\section{3 多様な書誌への対応}

カーリルのサービス開始当初は，Amazonの書誌情 報に対して全国の図書館の所蔵情報を紐付けること によりサービスを実現した。しかしAmazonの書誌 情報のみを利用した場合，図書館に所蔵があっても Amazonに登録のない書籍は検索結果に表示されな い。この問題に対応するため，多様な書誌情報や検 索先に対応している。

ISBNで検索した場合，「Amazon」の他，「国立国 会図書館サーチ」，「版元ドットコム」，「CiNii Books」 に該当するデータがある場合はカーリルでも表示で きる。

また，検索先として標準のAmazon APIに加えて， 国立国会図書館サーチAPIとOCLC Basic APIに対応し ている。現在は実験的な取り組みであるが，設定な どを簡略化し，より手軽に利用できるようにする予 定である。

\section{4 データセットの提供}

図書館の施設に関する情報源としてはカーリル， Wikipedia，saveMLAKなどのWebサイトや，国立 国会図書館が運用するISILや国立情報学研究所の 
NACSIS参加組織コードなどの各種コードに紐付いた データがある。

また，カーリルでも図書館単位のコードを付番し ており，APIによる所蔵情報の取得にはこのコードが 必要となる。

日本国内にある図書館についての施設情報やコ一 ドを結合し，相互運用性を高めるために施設情報を 横断的に結合するためデータセットを無償で提供し ている。

\section{5 図書館システムとのAPI連携の取り組み}

カーリルのスクレイピングによる所蔵情報の提供 は，Web-OPACの検索速度に影響されて，ユーザー へのデータ提供までに時間がかかるという問題があ る。図書館システムの持つ所蔵情報に対して，効率 的な検索インデックスを作成することにより，高速 な所蔵情報の提供が可能となるが，これには図書館 システムとのデータ連携を図る必要がある。

現在，カーリルと中津川市立図書館および図書館 システムの開発会社で協力し，図書館自身がAPIを提 供する試みを実験的に進めている。このAPIをカーリ ルでも利用することにより，ユーザーに高速に検索 結果を提供できるようになる見込みである。

\section{8. ビジネスモデルの模索}

カーリルの主な収入源は, Amazonのアフィリエイ トによる仲介手数料収入と，バナー広告，検索連動 広告によるものである。サーバー費用などの運用に かかるコストはこれらの収入で賄われている。

図書館のインフラとして，長期的に安定したサー ビスを提供できるよう，複合的な収入源の確保と， コスト管理を徹底することはわれわれの重要な課題 である。

今後，書店や出版社，図書館との提携を通じて新 たなビジネスモデルを模索していく。

\section{9.おわりに}

在住者だけではなく，広い範囲の利用者に貸出を 行っている公共図書館も多い。また大学によっては， 地域の住民や卒業生に図書館を開放している場合も ある。ぜひ一度，図書館に足を運んでみてはどうだ ろうか。カーリルがそのきっかけになれば幸いであ る。

\section{参考資料}

a) 洛西一周. ごぞんじですか？カーリル. 専門図書館. 2010, no. 242, p. 47-53.

\section{参考文献}

1) Libron. http://libron.net/, (accessed 2012-03-23).

2) Libreq. http://libreq.net/, (accessed 2012-03-23).

\section{Author Abstract}

Calil.JP is a new free online service that enables federated searching, marshalling and integration of Web- 
OPAC data on the collections of libraries from around Japan. It offers the search results through user-friendly interface. Developed with a concept of accelerating discovery of fun-to-read books and motivating users to head for libraries, Calil was initially designed mainly for public library users. It now extends to cover university libraries and special libraries. This article presents the Calil's basic capabilities, concept, progress made thus far, and plan for further development as viewed from an engineering development manager.

\section{Key words}

library, OPAC, library catalog, web service, federated search, local material, API, Calil, Calil Local, Calil Academia 